\title{
Strategy to Maintain the Cinema Industry in the Middle of Development of Internet Technology
}

\author{
Dipa Mulia' ${ }^{1}$ and Muchsin Saggaff Shihab ${ }^{2}$ \\ Universitas Mercubuana, Jakarta ${ }^{1}$ \\ Universitas Bakrie, Jakarta ${ }^{2}$ \\ E-mail:dipa.mulia@mecubuana.ac.id; muchsin.shihab@bakrie.ac.id
}

\begin{abstract}
Internet technology has been utilized in many sectors of business including in the film industry. People are using internet technology to replace the newspaper and television and also creating a new platform (computer, cellular phone and other types of gadget) to watch a film, it threats the cinema industry. This research aims to formulate the strategy of cinema industry to survive in the middle of internet technology. The motive of cinema-goers to watch the film becomes the main issue in this research. The influence of information, personnel film, word of mouth and cinema-quality to cinema-goers are evaluated. Hundred and twenty-eight cinema-goers involved as respondents. Structure Equation Modelling (SEM) is used to analyze the data. The research revealed that the cinema-goers had a specific expectation of the cinema industry that cannot be replaced by internet technology.
\end{abstract}

Keywords: Internet technology, Film quality, Cinema quality, Behavior of movie-goers.

\begin{abstract}
Abstrak: Perkembangan teknologi internet sudah merambah hampir ke dalam seluruh sektor usaha tidak terkecuali pada industri bioskop. Internet berhasil mengubah perilaku konsumen dan pola kerja pengusaha, teknologi ini melumpuhkan beberapa sektor usaha yang sudah mapan selama bertahun tahun, diantaranya adalah industri media cetak (seperti: surat-kabar dan majalah). Hal serupa diperkirakan pula mengancam industri bioskop. Penelitian ini bertujuan untuk memformulasikan strategi dalam mempertahankan usaha bioskop di era digital, yaitu suatu perioda waktu ketika teknologi internet mendominasi aktivitas manusia. Perilaku dan karakteristik konsumen bioskop menjadi titik berat penelitian ini. Karakteristik tersebut dicerminkan oleh variabel perilaku konsumen (penonton) bioskop yang diperoleh dari beberapa penelitian sebelumnya. Variabel yang mempengaruhi keputusan menonton film di bioskop dipelajari, yaitu ariabel Informasi Film, Personel Film, Word of Mouth dan Kualitas Bioskop. Menggunakan metoda analisis Structural Equation Modelling (SEM) variabel yang mencerminkan perilaku penonton dipelajari untuk merumuskan strategi industri bioskop dengan tujuan mempertahankan bisnis bioskop ditengah perkembangan teknologi internet. Penelitian ini menyimpulkan bahwa industri bioskop dapat bertahan dikarenakan kekhususan karakteristik bioskop yang tidak dapat digantikan oleh teknologi internet.
\end{abstract}

Kata kunci: Perilaku Penonton, Teknologi Internet, Kualitas Film, Kualitas Bioskop. 


\section{INTRODUCTION}

The digital era is the era when technology is so dominant and the rapid growth of internet users has changed the consumption patterns of society, especially in urban society, especially the millennial generation. The growth of internet users is also encouraging the growth of other technologies that are commonly used in business. The same thing happened in the cinema industry where at present the media as the platform for watching films has varied and cinema is not the only media platform for watching films. The invention of VCDs and DVDs that made it possible to watch movies at home or elsewhere outside the cinema had already existed, but the growth was not as fast as the growth of internet technology. Internet technology allows viewers to enjoy films through a variety of devices (mobile phones, smart TVs, computers) that are growing rapidly and even starting to reduce the role of media platforms that already existed (Chen et al., 2017). Referring to the experience of the print media industry which is affected by the development of internet technology, the cinema industry must take steps to be able to defend themselves from the development of internet technology which is starting to seem to disrupt several types of businesses that already existed. Nielsen's research report related to print media quoted by marketeer.com shows that public interest in reading has not decreased even though the number of print media and its penetration in the community has decreased. This is because people switch platforms from print to electronic media. As a result of changes in people's behavior in using the media platform as a source of information, then from time to time, there is a decrease in print media titles (newspapers and magazines) so that in time the print media will reach its lowest point (Bachdar, 2018).

The same thing happened in the television industry (television station), Nielsen's research in the Republika daily news showed that in some developed countries television program audiences had been replaced by the presence of gadgets with independent programming programs, such as YouTube and other streaming (Puji, 2016). The cinema industry is interesting to study because this industry has characteristics that are very similar both to the print media industry and the television station industry. The threat of internet technology to the cinema industry is estimated to be the same as that experienced by print media and television stations, to maintain this industry it is necessary to learn important things that can affect the existence of the cinema industry.

One of the things that should be learned is the behavior of consumers (cinema viewers) when deciding to go to the cinema. Research on movie-goers' behavior has been done quite a lot, but most of the research is qualitative so it is rather difficult to formulate a strategy that is worth taking to be able to sustain the cinema industry. The difference between this research and previous research is that this research is a quantitative study that studies the relationship between the behavior of the cinema audience and the decision to go to see a movie in the cinema. The behavior of cinema viewers is measured by several indicators that can be quantified as well as the decision to watch at the cinema. Quantitative analysis is carried out using Structure Equation Modeling (SEM). The main objective of this research is to formulate an appropriate strategy for cinema entrepreneurs that is adjusted to consumer behavior in the current digital era so that the cinema industry can survive amidst the growth of internet technology so that it does not end up like print and television media which are starting to decline due to the development of internet technology. 


\section{THEORETICAL REVIEW}

The literature used in this study are mostly journals that convey concepts related to consumer motivation in deciding to watch movies in theaters or better known as moviegoers. Not overly many libraries that discuss movie-goers, most of the current research is qualitative. (Pangarker and Smit, 2013) revealed that the films that were favored by the audience were usually films made with high costs, produced by well-known producers, films that were nominated for awards and films which were sequels from the previous story. Other studies explained qualitatively that the motive of the audience to come to the cinema is not merely to watch a movie, even $70 \%$ of the audience has not yet determined what film to watch when coming to the cinema (Kaye, 2014). One of the motives of the audience to come to the cinema is trying to get a new atmosphere outside the existing routine, the audience's desire to forget themselves from their current situation such as being bored, tired, bored and expecting to get something better when seeing a movie in the cinema. The audience also uses the cinema as a place to socialize and gather (Luckett, 2013). The motivation of the cinema viewers naturally does not change from time to time, the audience only strives to strike a balance between routine daily activities with the need to relax (relax) or do social interaction in the cinema. (Van de and Biltereyst, 2013).

Watching movies in the cinema is an effort to gain experience and interaction with others not just to enjoy it with others, this is conveyed in the theory of collective spectatorship (Hanich, 2014). Referring to previous research studies it is stated that the audience coming to the cinema can be triggered by the quality of the film which is judged both by the audience and/or the quality of the cinema following audience expectations. Film and cinema are the products that together motivate the audience to attend the cinema, this is under the study which concluded that the interest in watching movies in the cinema is not only determined by what is on the cinema screen but also is determined by the time and place where the screen is (Aveyard and Moran, 2013) or in other words in addition to the quality of the film that affects the audience to attend the cinema also the influence of the atmosphere of the cinema or the quality of the cinema.

This study adapted some previous studies which stated that the audience's decision to watch films in the cinema was influenced by two main things, aspects of film and aspects of cinema. Both the quality of the film and the quality of cinema both motivate the audience to see the film in the cinema. The quality of cinema and film quality influence the decision to watch a movie in the cinema in line with previous research related to Product Quality that affects purchase interest as expressed in several journals including (Saleem et al., 2015). In addition to Product Quality, some researchers also conveyed other variables that also influenced Purchase Intention, namely Word of Mouth (WoM) or electronic Word of Mouth (e-WoM), one of the studies that revealed this was done by (Bataineh, 2015). WoM is a consumer comment related to a product is delivered to other consumers conventionally while e-WoM is a consumer comment delivered through electronic devices or internet media.

The main aspects that affect movie-goers in the cinema, aspects of film quality, cinema-quality and public opinion or opinion that are selected as variables in this study. Related to aspects of film quality, this study sets two latent variables, variables of Film Information and variables of Film Personnel (Star and Film Director). Cinema quality is a latent variable that is explained by several indicators of consumer perception obtained from 
previous studies. Public opinion and comments are conveyed in one latent variable, the word of mouth (WoM) variable. The relationship between the variable Film Information, Film Personnel, WoM, and Cinema Quality to the interest in watching films in theaters is depicted in the relationship in Figure 1. The model of this study describes four independent variables, Film Information, Film Personnel such as Stars and Directors, WoM and Cinema quality that affects one dependent variable is the decision to watch at the cinema. The hypothesis developed in this study is that all independent variables influence the dependent variable.

Figure 1. Research Mode

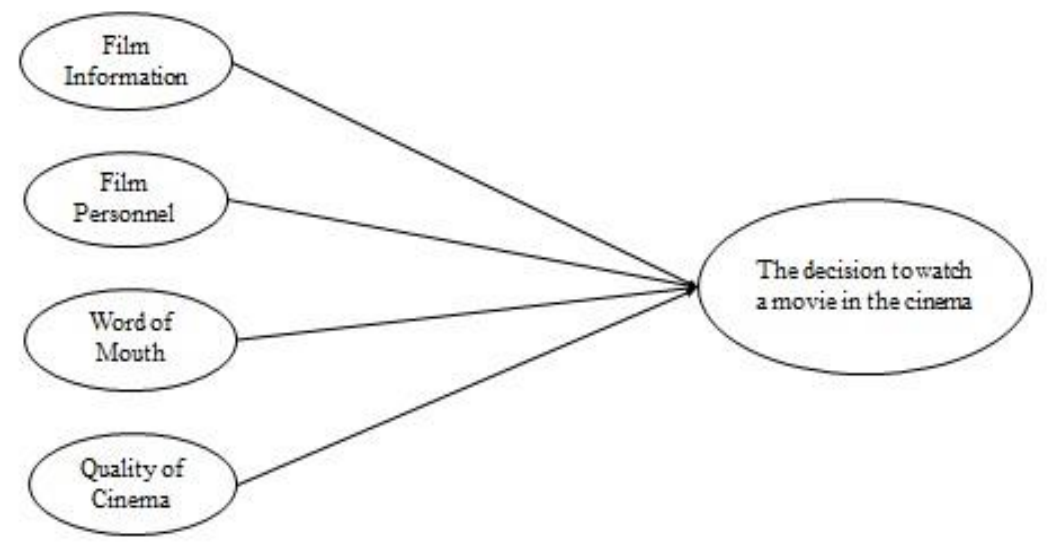

Film Information. Film information is an effort of film producers to convey matters relating to the film to prospective viewers or the public with the aim that the public is familiar with the film and makes the decision to watch the film. Film information can be conveyed in various places using various media. Film information as one of the latent variables in this study is explained by two main indicators, film advertisements and film trailers. Both film advertisements and film trailers are media that can be used to convey information about films. Advertising is usually in the form of paid promotions carried out by product owners through various media both traditional media such as Television, Radio, Magazines, and billboards or digital media such as social media, internet, etc. (Ahmed and Ashfaq, 2013). Movie advertisements included in this study are film advertisements delivered in the form of posters in the cinema waiting rooms or advertisements delivered in other public spaces such as newspapers, magazines, billboards and also advertisements delivered through social media, etc. Advertising is one of the significant factors influencing consumer behavior in deciding to buy a product (Haider and Shakib, 2017). Film Trailer is a trailer or part of a film that is considered to make the viewer interested in watching a movie because the film trailer involves the emotions and expectations of the viewer who think that the film will fit the existing trailer even though research shows that the audience is often disappointed because the trailer does not reflect the actual contents of the film (Johnston et al., 2016). Research showed that film information, especially in the form of trailers designed with narrative and persuasive content, turns out to be a stimulus for viewers to decide to buy cinema tickets (Barnett et al., 2016). Previous research studies showed that film and trailer advertisements are commonly used instruments to introduce products (films) which 
motivate the audience to decide to watch the film being introduced. The selection of film information variables in this study was also supported by previous research studies.

Star and Film Director. The success of a film is usually measured by its ability to generate income or what is known as the box office, this is largely determined by external factors, advertising and promotion and also internal factors, Director and Film Star both actors and actresses (Bioglio and Pensa, 2018). Film stars and directors are key personnel in filmmaking, indicators used in measuring key personnel in this study are the personnel's fame, experience, and achievements. Research conducted in China showed that there is a positive relationship between film stars and income from a film (Liu et al., 2015). Research conducted in the United States showed that reputable directors greatly help film performance both financially and non-financially (John et al., 2017). Research in China showed that films that score good income or good performance are influenced by the budget of filmmaking, the selection of actors and directors, the storyline (sequels) (Elliot et al., 2018). One of the big-budget is to pay high-quality movie stars. The selection of high-priced film stars showed that producers are willing to spend a high budget on filmmaking and film stars believe that the films made are of good quality (Akdeniz and Talay, 2013). Films that require an award nomination are also considered by the audience (Pangarker and Smit, 2013). The selection of the strength of film personnel, in this case, the director and film star (actor) as one of the variables in this study was also supported by previous researchers.

Word-Of-Mouth (WOM). WOM is a comment or opinion from people around both positive and negative related to the experience in using the product. WOM is informal communication among consumers that reveals consumers' perceptions of the quality of a product, brand or other attributes of the product (Hausmann and Poellman, 2016). Word of mouth can be delivered through the internet or other social media which is a means for consumers to express opinions that greatly influence other consumers in making decisions (Saveri et al., 2014). Related to the topic of film and cinema, what is meant by WOM in this study is the commentary of the audience's experience related to film or cinema. Judgments submitted by many parties related to one film affect the prospective audience to decide whether to watch or not, while audience comments related to the condition of the cinema are expected to influence other prospective viewers to come to the cinema. This word of mouth can be in the form of audience comments on social media, film reviews delivered in various media or the comments of film critics. One study showed that comments from professional critics greatly influenced the audience's decision to see the film in the cinema, both positive and negative comments. It should be noted that negative comments are more powerful than positive comments (Gunter, 2018). The success of a film is not only determined by key personnel in filmmaking but also by the ability to form opinions in the community through word of mouth (Hennig et al., 2015). Other research showed the influence of social media Twitter on film viewers, positive comments delivered via twitter increase the number of viewers and vice versa negative comments decrease the number of viewers. (Rui et al., 2013). Watching a film is an experience that can only be assessed for quality after the process is carried out to avoid getting unfavorable quality the audience relies on comments (reviews), film critics, word of mouth from social media or electronic Word of Mouth (e-WoM) (Kim et al., 2013). 
Cinema Quality. Cinema quality is a variable that is estimated to influence whether prospective viewers, in addition to being interested in watching films, also decide to go to the cinema. This is an important part of this research because this research aims to formulate a strategy so that the cinema business can survive amid the development of internet technology. The quality of cinema in this study includes the location of the cinema, showtimes, and atmosphere in the cinema such as the atmosphere of the waiting room, the ticket purchase process, the screening room, and the sound technology used. Previous studies have even considered the effect of using fragrance in the cinema (Verissimo and Alves, 2013). The queue in ticket purchases was also a concern of several previous studies, the queue resulted in frustrated viewers and even canceled the intention of watching a movie in the cinema. Efforts to overcome the queue provide satisfaction and increase the interest of the audience (Dabholkar, 2015). The location of the cinema and the size of the cinema room also caught the attention of the audience (Jones, 2019). The availability of tickets and the choice of air-time is part of the availability of the cinema industry, for that airtime becomes one of the indicators of cinema-quality. Changes in cinema design that occur in the United States and the United Kingdom from a large cinema with one big screen to a smaller cinema with a smaller screen (Cineplex) is an effort to improve the quality of the cinema to match the wishes of the audience (Hanson, 2013).

Cinema Quality. Cinema quality is a variable that is estimated to influence whether prospective viewers, in addition to being interested in watching films, also decide to go to the cinema. This is an important part of this research because this research aims to formulate a strategy so that the cinema business can survive amid the development of internet technology. The quality of cinema in this study includes the location of the cinema, showtimes, and atmosphere in the cinema such as the atmosphere of the waiting room, the ticket purchase process, the screening room and the sound technology used. Previous studies have even considered the effect of using fragrance in the cinema (Verissimo and Alves, 2013). The queue in ticket purchases was also a concern of several previous studies, the queue resulted in frustrated viewers and even canceled the intention of watching a movie in the cinema. Efforts to overcome the queue provide satisfaction and increase the interest of the audience (Dabholkar, 2015). The location of the cinema and the size of the cinema room also caught the attention of the audience (Jones, 2019). The availability of tickets and the choice of airtime are part of the availability of the cinema industry, for that airtime becomes one of the indicators of cinema-quality. Changes in cinema design that occur in the United States and the United Kingdom from a large cinema with one big screen to a smaller cinema with a smaller screen (Cineplex) is an effort to improve the quality of the cinema to match the wishes of the audience (Hanson, 2013).

The decision to Watch Film in Cinema. The decision to watch a movie in a cinema is somewhat different from some previous studies which only measure interest in watching a movie without considering the chosen platform. The platform for watching movies can be in the form of cinema, DVD (home theater), streaming, etc. The most important thing in this study is the decision of the audience to visit the cinema. The latent variable Movie Decision Watch in Cinema is explained by two indicators, the indicator recommends watching in the cinema and the indicator of watching a new film at the beginning of its launch. This was chosen considering the purpose of this research is to maintain the cinema industry in the era of internet technology. Recommending to watch a movie in a cinema is one of the things 
that causes the number of cinema viewers to survive while watching a film at the beginning of the launch is considered important because most of the newly released films are usually screened in the cinema before being played on other media (platforms). Long-circulated films can be obtained on DVD, video streaming and other platforms. The decision to watch a movie in a cinema is somewhat different from some previous studies which only measure interest in watching a movie without considering the chosen platform. The platform for watching movies can be in the form of cinema, DVD (home theater), streaming, etc. The most important thing in this study is the decision of the audience to visit the cinema. The latent variable Movie Decision Watch in Cinema is explained by two indicators, the indicator recommends watching in the cinema and the indicator of watching a new film at the beginning of its launch. This was chosen considering the purpose of this research is to maintain the cinema industry in the era of internet technology. Recommending to watch a movie in a cinema is one of the things that causes the number of cinema viewers to survive while watching a film at the beginning of the launch is considered important because most of the newly released films are usually screened in the cinema before being played on other media (platforms). Long-circulated films can be obtained on DVD, video streaming and other platforms.

\section{METHODOLOGY}

Following the research objective, which is to formulate a strategy to maintain the cinema business in the growth of internet technology in the digital era, this research was made by considering the variables concerning the consideration of film audiences in the cinema in making decisions as illustrated in the framework of thinking (Figure-1). This study studies the relationship between the independent variable and the dependent variable, which in the end this research formulates what needs to be done on the independent variable (Film Information, Star and Film Director, Word of Mouth, Cinema Quality) so that the performance of the dependent variable (Decision to Watch Film in Cinema) as desired, as illustrated in the research model. The flow of research is as follows:

Problem Formulation. As already stated, the formulation of the problem in this research is the effort to maintain the number of cinema viewers when the emergence of other media as a substitute for cinema supported by internet technology.

Research Models. The research model presented in Figure 1 is to look for the relationship of independent variables that describe the quality of the film (Film Information and Film Personnel) and the Quality of My scopes and WOM with the dependent variable namely interest in watching movies in the cinema.

Preliminary Research. Preliminary research was conducted using independent variables and dependent variables and indicators for each variable. This preliminary study surveyed 30 respondents to agree on the reliability of the model. Respondents are members of the community in the DKI area who are film lovers.

The selected independent variables and their indicators are: (1) Film information is explained with indicators: film advertisements, scenes in the trailer and image quality in the 
trailer. (2) Director and Film Star (Personnel Film) explained using indicators of experienced personnel, famous personnel, personnel who excel. (3) Word of Mouth is explained with indicators of social media comments, comments (reviews) of film critics, and reviews of films in trusted media. (4) Cinema quality is measured by indicators: cinema location, movie show-times, cinema atmosphere.

Dependent variable. As the dependent variable is the decision to watch in the cinema (the penchant for watching films in the cinema) measured by indicators, recommending watching movies in theaters and interest in watching new films in the cinema at the beginning of time.

Data Collection. Data is collected in the DKI Jakarta and surrounding areas (JABODETABEK) using a questionnaire submitted to respondents who meet certain criteria. Respondents are consumers who have watched movies in theaters. The number of respondents in this study was at least 100 people. The sampling method is done by purposive sampling method.

Data Analysis. Stages of data analysis were initiated by Confirmatory Factor Analysis (CFA) using SEM (lisrel) to test construct reliability and indicator validity. The analysis is continued by formulating the relationship between the exogenous latent variable (the independent variable) and the endogenous latent variable (the dependent variable). The structural relationship of this variable is expressed in an equation (equation) in the form of multiple regression (Wiranto, 2015).

Discussion/Interpretation of result. The result of the data analysis in the form of calculations and statistical figures which then need to be broken down into managerial language, so that the description of the problem and discussion becomes easier to understand.

The conclusion is the result of hypothesis testing which shows the level of significance and weight of the influence of independent variables on the dependent variable so that efforts can be formulated to increase the number of cinema viewers.

\section{THE RESULTS OF STATISTICAL TESTS}

Preliminary Research. The results of the preliminary study using 30 samples showed that the data and measuring instruments have adequate reliability and validity with Cronbach's Alpha number of 0.851 which is greater than the critical value of 0.7 and the Pearson correlation is greater than the $r$ table of 0.37 . The study was declared feasible to proceed by using variables and indicators that were determined under preliminary research.

Research Data Characteristics. This research continues preliminary research that uses questionnaires as a tool to get data from consumers who are film fans (viewers). Researchers managed to collect 128 respondents, after being evaluated all respondents' data were declared to be eligible for further processing. The composition of respondents is divided into $45 \%$ female respondents and 55\% male respondents. While from the age composition 
of the majority of respondents aged around $26-45$ years is equal to $65 \%$, while the age of under 26 years is $34 \%$ and for respondents over the age of 45 years only $1 \%$. Almost all respondents stated that watching movies was more often done together with relatives or family. The composition of these respondents can be stated to be a picture of consumers of film viewers in general.

Confirmatory Factors Analysis (CFA). This study involved four independent variables with one dependent variable. These five variables are latent so indicators are needed to explain them. CFA is done not only to assess the validity of the indicators forming the variable indicators is a good indicator in explaining latent variables but also to obtain a comparison number between indicators in explaining variables, this is reflected in the loading factor figures. Following is the result of the CFA for the indicators used and the reliability of the indicators with the variables they describe.

Table 1. Test Reliability and Validity

\begin{tabular}{|c|c|c|c|c|c|}
\hline Variables & Indicator & Description & $\begin{array}{c}\text { t- } \\
\text { value }\end{array}$ & Load & $\mathbf{C R}$ \\
\hline Film & 11 & Advertising & 5.04 & 0.32 & 0.74 \\
\hline \multirow{2}{*}{ Information } & 12 & The scene in the trailer & 8.60 & 0.56 & \\
\hline & 13 & Image quality in the trailer & 8.90 & 0.58 & \\
\hline \multirow{3}{*}{$\begin{array}{l}\text { Star and } \\
\text { director }\end{array}$} & $\mathrm{P} 1$ & Famous & 7.97 & 0.76 & 0.75 \\
\hline & $\mathrm{P} 2$ & Experienced & 8.26 & 0.70 & \\
\hline & P3 & Award winner & 7.85 & 0.76 & \\
\hline \multirow{3}{*}{$\begin{array}{l}\text { Word-Of- } \\
\text { Mouth }\end{array}$} & W1 & Comment on social media & 5.09 & 0.47 & 0.73 \\
\hline & W2 & Movie critic review & 9.66 & 0.80 & \\
\hline & W3 & Media review & 8.96 & 0.74 & \\
\hline \multirow[t]{5}{*}{ Cinema quality } & Q1 & The sound quality in the & 6.75 & 0.39 & 0.76 \\
\hline & Q2 & cinema & 6.35 & 0.59 & \\
\hline & Q3 & Cinema location & 8.26 & 0.75 & \\
\hline & Q4 & Movie show-time & 8.96 & 0.63 & \\
\hline & & $\begin{array}{l}\text { The atmosphere of the } \\
\text { cinema }\end{array}$ & & & \\
\hline \multirow{3}{*}{$\begin{array}{l}\text { Watch in the } \\
\text { cinema }\end{array}$} & D1 & Recommend watching in the & 7.70 & 0.98 & 0.82 \\
\hline & D2 & cinema & & & \\
\hline & & $\begin{array}{l}\text { Watch in the cinema at the } \\
\text { beginning of the film's launch }\end{array}$ & 7.75 & 0.94 & \\
\hline
\end{tabular}

Goodness of Fit Test. Index measurements that reflect the suitability of the model in this study give the following results:

Goodness of Fit Index $(\mathrm{GFI})=0.85$

Comparative Fit Index $(\mathrm{CFI})=0.92$

Normed Fit Index $(\mathrm{NFI})=0.87$

$\mathrm{P}-$ value $($ for RMSEA $<0.05)=0.000$ 
Structural Equation Modeling. The relationship between the independent variable and the dependent variable is shown by the following multiple linear equations

\section{Interest in Watching Cinema $=0.099$ Film Information +0.2 Film Personnel +0.27 WOM + 0.32 Cinema Quality}

The level of significance of the relationship between the dependent variable and the independent variable is conveyed by showing the t-value. Film information has a t-value of 0.96, Film Personnel with a value of $t 1.56$, Word-Of-Mouth has a t-value of 1.97 while Cinema Quality has a t-value of 2.82. This equation has an $\mathrm{R}$ squared (coefficient of determination) of 0.48 or $48 \%$.

\section{DISCUSSION}

The result showed that all indicators can be declared feasible in explaining latent or valid and reliable variables. This is indicated by a t-value greater than 1.96 for each indicator and has a loading factor greater than 0.3 (Geldhof et al., 2014) although some researchers require a loading factor greater than 0.4 to state the validity of the indicator. Construct Reliability $(\mathrm{CR})>0.7$ for all variables, meaning that all variables used in this study are reliable (Sharma, 2016).

The latent variable Film Information is explained distinctly well by the Film Trailer indicator, both related to the scene in the trailer or the image quality of the trailer. Indicators related to movie trailers have a closer relationship with the Film Information variable compared to the Film Ad indicators. This showed that viewers feel the trailer is more informative than film advertisements. The latent variables of Film Star and Director (Personnel Film) are well explained by the experience of film personnel, the appreciation, and the popularity of personnel (film stars and directors). The audience pays more attention to indicators of personnel experience as the main explanation of the variable Film Star and Film Director. Word-Of-Mouth (WOM) for the film and cinema industry is better explained by critically commented films and film reviews and cinemas in reliable media. Nevertheless, consumer comments delivered through social media are also good enough to explain the WOM variable. Related to Cinema Quality, cinema show-time indicator has a precisely high closeness in explaining cinema-quality, then followed by cinema atmosphere and cinema location indicators. A variable decision to watch in the cinema which is defined as a love to watch a movie in the cinema is well explained by behavioral indicators to recommend and love to watch a movie at the beginning of its launch in the cinema.

The model used in general is marginally compatible. GFI which is an indication of overall model fitness (overall - fitness) with a value of 0.85 , the criteria of the model are stated to be very good if it has a GFI> 0.9. Comparative Fit Index (CFI) is an incremental conformity index. This CFI is relatively insensitive to sample size and model complexity, therefore this index is more appropriate to be used as an indicator of model compatibility. The recommended CFI value is CFI> 0.90, this study gives a CFI value of 0.92 , based on the CFI measurement criteria, the model is declared precisely good. Normed Fit Index (NFI) is a measure of comparison between proposed models and null models. The null model, in general, is a model that showed that the variables contained in the model are not interconnected. The recommended NFI value is $>0.90$, this study gives an NFI value of 
0.87. Probability Chi-squares value $>0.05$ indicated empirical data is identical to theory or model, in this study empirical data is identical to the model. (Wijanto, 2015).

All independent variables have a positive relationship with the dependent variable but not all independent variables have a significant relationship with the dependent variable. Using the criterion t-value $>1.96$, the independent variable Film Information and the independent variable Film Personnel (Film Star and Director) have an insignificant relationship with the decision to watch a movie in the cinema. The trailer as one of the indicators that particularly closely explains film information is an effective medium for introducing films and inviting viewers to watch films. Even though the viewer's experience stated that movie trailers often don't match the actual film, the trailer is usually better than the actual film so the viewer is not significantly sure that the movie will match the trailer delivered. This study showed that the variable Personnel Film (Film star and film director) is not a significant variable influencing the audience to attend the cinema. Although some studies showed that film stars and directors are one of the driving forces for viewers to watch films, but these studies are not specific to the interest in watching movies in theaters because it is possible for the film to be watched but by using other media besides cinema. Film Information and Film Personnel are variables that are related to film quality, in other words, it can be stated that film quality does not significantly influence the audience's decision to watch films in the cinema. The result of this study reinforces previous research which states that viewers who come to the cinema have not even chosen or determined the title of the film to watch before coming to the cinema, or in other words, the audience does not have a preference for the film when it comes to cinema. This research also showed that film is not the main driving factor for viewers to come to the cinema. Viewers come to the cinema regardless of the quality of the film.

WOM Variable and Cinema Quality have a positive and significant relationship with the decision to watch a movie in the cinema. The highest coefficient is shown by the quality of cinema with a value of 0.32 while WOM of 0.27 . WOM in this research includes audience comments on social media, comments from film critics, film reviews in trusted media. The result of this study indicated that the comments of other parties besides the producers significantly influence the prospective audience in deciding to watch a movie in the cinema. WOM's role in motivating the audience to attend the cinema is in line with previous research. This research revealed that viewers obtain to have film information other than those delivered by producers in the form of film advertisements and trailers as well as from fellow consumers in the form of comments on social media and comments from film critics in other trusted media. The information conveyed by the producer does not significantly influence the audience in deciding to watch in the cinema but the comments of other viewers have a significant effect. This showed that the response of other viewers is more trustworthy by prospective viewers than the information conveyed by the producers. WOM is an excellent instrument for delivering messages and recommendations. This is particularly beneficial because consumers trust the recommendations of friends, family and other consumers (Hossain et al., 2015).

The quality of the cinema in this study included sound quality, show-time at the cinema, the location of the cinema and the atmosphere of the cinema. The audience comes to the cinema because of the quality of cinema support, this is under previous research that the cinema is a place to socialize the audience. Cinema show-time indicators and cinema atmosphere explained well the cinema-quality variable. The audience comes to the cinema 
as an effort to acquire a new atmosphere and get out of the routine, for that it takes time following the free time. Cinema time available is a major consideration for the audience. The atmosphere of the cinema includes the atmosphere of the waiting room, the atmosphere of the ticket queue and the atmosphere of the place when the film is playing. The cleanliness and comfort of the place are considered by the audience to watch a movie in the cinema. The effort of cinema entrepreneurs to improve the atmosphere of the cinema is done starting from the improvement of the waiting room, ticket queues to screen modifications and others is an effort to make the audience feel comfortable coming to the cinema.

This study also strengthens the opinion of previous researchers as conveyed in the study of the theory that other motives of the audience coming to the cinema besides watching the film also interact with other audiences (Luckett, 2013). The collective spectator theory even stated that film is not the only important thing when the audience comes to the cinema. Existing technology can create a home-like a cinema, using a good sound system, a widescreen so that technically the house resembles a bishop (home theater). Nevertheless, film viewers still come to the cinema to watch films, this is because watching movies at home (home theater) does not obtain an atmosphere of togetherness and interaction between the audience. The function of cinema as a means of bringing together audiences cannot be replaced by other media including home theater or using other media that is assisted by internet technology. This is confirmed by the result of the questionnaire which states that almost all respondents said that they came to the cinema not alone but collectively (together).

The interesting thing in this study that has not been discussed in previous studies is a quantitative analysis between variables that strive to be able to measure the significance of the influence of each independent variable and also the magnitude of the effect on the dependent variable, thus it can be compared realistically the effect of each independent variable on the variable bound. By the research objective of formulating the strategy of the cinema industry to increase the number of cinema viewers, it can be stated that the main priority that needs to be done to maintain or increase the number of viewers in the cinema is to improve the quality of cinema and to make WOM effective. The most appropriate indicator for cinema-quality is cinema show-times that have a loading factor of 0.75 and $\mathrm{t}$ value 8.26, then a cinema atmosphere that has a loading factor of 0.63 and a t-value of 8.96. Word-Of-Mouth (WOM) needs to be activated as a means of delivering information, film critics and media reviews are significantly good indicators of explaining WOM variables with loading factors of 0.80 and 0.74 , in addition to audience comments on social media with loading factors of only 0.47 .

The dominance of the quality of cinema to the interest of the audience present in the cinema by the theory that has been conveyed that some of the cinema viewers use the cinema as a place to balance daily activities and find other places to socialize and relax. The function of the cinema is not just a place to watch movies where this function cannot be replaced by other media to watch films including media facilitated by internet technology. Cinema entrepreneurs should not be worried about the presence of internet technology which is expected to disrupt the cinema industry, this is because there are several things consumers expect from cinemas that cannot be replaced by internet technology such as the need to socialize and interact with other audiences. Cinema entrepreneurs can utilize internet technology to improve the quality of cinema so that the interest of the audience to attend the 
cinema increases. This research showed that the quality of cinema is very closely related to movie show-times in cinemas and cinema atmosphere.

Word-Of-Mouth (WOM) is a variable that also influences the audience's decision to watch a movie in the cinema. Indicators of film critic comments and media reviews are closely related to the WOM variable. Internet technology can be utilized to increase the effectiveness of film critic comments and media reviews so that the penetration of film critic comments and media reviews increases to prospective audiences widely.

The independent variable in this study can explain the independent variable by $48 \%$ while the remaining $52 \%$ is explained by other variables not listed in this study. A vast opportunity is opened to continue this research by studying other aspects that affect the audience present in the cinema.

\section{CONCLUSION}

The result of the study concluded that the variable Film Information and Film Personnel did not significantly influence interest in watching movies in theaters, while the variable Quality of Cinema and Word-Of-Mouth (WOM) had a positive and significant effect. This research showed that the main motivation of the audience present to the cinema is not to consider the quality of the film but rather the quality of the cinema. Efforts that can be made to increase the interest of cinema viewers are improving cinema quality and providing comments related to films and cinema through word of mouth either conventionally or through the internet and social media (e-WOM) because WOM is more significantly affecting the audience to come to the cinema compared to with film or trailer advertisements.

Implications of Research Result. One effort to increase interest in watching movies in the cinema should be that the cinema industry adjusts the film's show-times at the cinema to match the target audience's activities. Movie show-time is an important matter for the audience to consider when deciding to watch a movie in the cinema. For certain regions, it may take airtime until midnight on weekends but in certain areas, it takes an earlier flight time especially on holidays. Also, according to the result of research indicators that can explain the quality of cinema is the atmosphere of the cinema, this is related to the comfort of the audience while in the cinema. The queue in buying tickets is one of the things that concern the audience, to overcome this online ticket program should be a priority for the cinema industry to do. Another thing that can be done is to increase the effectiveness of Word-Of-Mouth (WOM) in the form of critic comments and media reviews by using internet technology to become e-WOM so that the penetration of e-WOM towards potential prospective viewers becomes more effective. Further research can be done by considering several aspects such as: knowing better the audience's perception of the comfort of the cinema, the effectiveness of the use of internet technology in WOM because prospective viewers consider other audience comments rather than advertisements delivered by producers. Further research can also be done by considering other independent variables considering the independent variables in this study are only able to explain the dependent variable by $48 \%$ (coefficient of determination), besides that in this study there are several independent variables (independent) that do not significantly influence the dependent variable (dependent ). 


\section{REFERENCE}

Ahmed, S. and Ashfaq, A. (2013). "Impact of Advertising on Consumer Buying Behavior Through Persuasiveness, Band Image, and Celebrity Endorsement". Global Media Journal, 6 (2).

Akdeniz, M. B., and Talay, M. B. (2013). "Cultural Variations in the use of Marketing Signals: A Multilevel Analysis of the Motion Picture Industry". Journal of the Academy of Marketing Science, 41(5), 601-624.

Aveyard, Karina and A Moran. (2013). Watching Film: New Perspective on Movie Going, Exhibition and Reception, Bristol: Intellect.

Bachdar, S. (2018). Masa Depan Media cetak dari Digitalisasi hingga Masalah Gaji, (https://marketeers.com) downloaded in December 2019.

Barnett, Samuel B., Hope M. White, and Moran Cerf. (2016). "Keep It Simple Stimuli: Brain-Vetted Elements of Movie Trailers Predict Opening Weekend Ticket Sales", Advances in Consumer Research, 44.

Bataineh, A.Q. (2015). "The Impact of Perceived e-WoM on Purchase Intention: The Mediating Role of Corporate Image", International Journal of Marketing Studies, Vol 7 No. 1 .

Bioglio, Livio and R.G. Pensa. (2018). "Identification of Key Film and Personalities in the History of Cinema from a Western Perspective", Applied Network Science, 3:50.

Chen, Y. M., Liu, H. H., and Chiu, Y.C. (2017). "Customer benefits and value creation in streaming services marketing: a managerial cognitive capability approach", Psychology \& Marketing, 34(12), 1101-1108.

Dabholkar, P. A. (2015). "How to Improve Perceived Service Quality by Increasing Customer Participation", Academy Marketing Science, Springer International Publisher.

Elliot, C., Konara, P., Ling, H., Wang, C. and Wei, Y. (2018). "Behind Film Performance in China's Changing Institution Context: The Impact of Signals", Asia Pacific Journal of Management, Vol 35, pp $63-95$.

Geldhof, G. J., Preacher, K. J. and Zyphur, M. J. (2014). "Reliability Estimation in a Multilevel Confirmatory Factor Analysis Framework". Journal of Psychological Methods 2014, Vol. 19, No. 1, 72-91.

Gunter, Barrie. (2018). Predicting Movie Success at the Box Office, Palgrave Macmillan, Springer Nature, Switzerland.

Haider, T. and Shakib, S. (2017)."Study on Influence of Advertisement on Consumer Buying Behavior", Business Study Journal, Vol 9, issue: 1.

Hanich, J. (2014). "Watching a Film With Others: Towards a Theory of Collective Spectatorship". Screen, 55(3), 338-359. https://doi.org/10.1093/screen/hju026.

Hanson, Stuart. (2013), "A 'Glittering Landmark for the $21^{\text {st }}$-Century Entertainment Center': The History of the Point Multiplex Cinema in Milton Keynes", Historical Journal of Film, Radio, and Television.

Hausmann, A. and Poellman, L. (2016). "eWOM in the performing arts: exploratory insights 'for the marketing of theaters", Arts and the Market, Vol. 6 No. 1, pp. 111-123.

Hennig, T., Wiertz C. and Feldhaus F. (2015). "Does Twitter Matter? The Impact of Microblogging word of mouth on consumer's adoption of New Movies", J Acad Mark Sci 43(3). 
Hossain, Md Akram, Sultana, N. dan Biswas S. (2015). "Evaluation the Effectiveness of Word of Mouth Marketing in Opposition to Traditional Advertising Concerning Medical Treatment Facilities in Bangladesh", Management and Organizational Studies Vol. 2, No. 1; 2015 DOI:10.5430/mos.v2n1p143.

John, S. K., Ravid, A., and Sunder, J. (2017). "Managerial Ability and Success: Evidence from the Career Paths of Film Directors". Journal of Corporate Finance, 44, 425439.

Johnston, K.M., Vollans, E., Greene, F.L. (2016). "Watching the Trailer: Researching the Film Trailer Audience", Participation, Journal of Audience and Reception Studies. Vol 13 (2).

Jones, J. (2019). “These Intimate Little Places': Cinema-Going and Public Emotion in Bolton: 1930-1954, The Journal of Social History Society, Vol 16 (4).

Kaye, B., (2014). A New Study Reveals America's Movie Viewing Habits, Entertainment News, (http://consequenceofsound.net/2014/11/new-study-reveals-americas-movieviewing-habits/) downloaded in December 2019.

Kim, S. H., Park, N. and Park, S. H. (2013), "Exploring the Effects of Online Word of Mouth and Expert Reviews on Theatrical Movies' Box Office Success". Journal of Media Economics, 26(2), 98-114. https://doi.org/10.1 080/08997764.2013.785551.

Liu, A., Tridib, M., and Li, B. (2015). Counterfactual Decomposition of Movie Star Effects with Star Selection. Management Science, 61(7), 1704-1721.

Luckett, M. (2013). Cinema and Community: Progressivism, Exhibition, and Film Culture in Chicago, 1907- 1917. Detroit, MI: Wayne State University Press.

Pangarker N. A. and Smit. E. M. (2013). "The Determinant of Box Office Performance in The Film Industry Revisited", South Africa Journal of Business Management, 44(3).

Puji, S. T. (2016), Nasib Televisi di Era Internet, (https://www.republika.co.id) downloaded in December 2019.

Rui, H., Liu, Y. and Whinston, A. (2013). "Whose and What Chatter Matters? The Effect of Tweets on Movie Sales". Decision Support Systems, 55(4), 863-870.

Saleem, A., Abdul G., Muhammad I., Muhammad Y. and Naveed A. (2015). "Product Perceive Quality and Purchase Intention with Customer Satisfaction, Global", Journal of Management and Business Research, E: Marketing, Vol 15 (1).

Severi, E., Ling, K. C. and Nasermoadeli, A. (2014). "The Impacts of Electronic Word of Mouth on Brand Equity in the Context of Social Media". International Journal of Business and Management, 9(8), 84.

Sharma, S. (2016). Applied Multivariate Techniques, (https://pdfentity.co) downloaded Desember 2019.

Van de Vijver, L and Biltereyst D. (2013). "Cinemagoing as a Conditional Part of Everyday Life. Memories of Cinemagoing in Ghent from the 1930s to the 1970s", Cultural Studies, 27, 4, pp.561-584.

Verissimo, J, and Alves, P. (2013). "The Effect of Ambient Scent on Moviegoers Behavior", Portuguese Journal of Management Studies, ISEG, Universidade de Lisboa, Vol 02.

Wiranto, Setyo Hari. (2015). Metode Penelitian menggunakan Structural Equation Modelling dengan LISREL 9, Cetakan Pertama, Penerbit Grha Ilmu. 